\section{IJ§ER}

ISSN: 2149-5939
International Journal of Social Sciences and Education Research

Online, http://dergipark.gov.tr/ijsser

Volume: 4(1), 2018

\title{
The movement of proceedings in accordance with the actual national legis- lation in Bulgaria
}

\author{
Rumen Vassilev ${ }^{1} \quad$ Vesela Mareva $^{2}$ \\ Received Date: 19 / 08 / 2017 \\ Accepted Date: 25 / $10 / 2017$
}

\begin{abstract}
The analysis of the topic aims at presenting the authors point of view, supporting the process of training students and all those interested in the topic of the possibilities of deviating from criminal proceedings child offenders and the temporal aspect of action. The authors present only a brief view of this extremely broad and important topic of law enforcement. The idea of the authors is to familiarize students with the thesis of the social and legal significance of the movement (the time horizon of preparation and realization) of educational cases, as an element of particular importance for children offenders, in which society is particularly sensitive.
\end{abstract}

Keywords: Legislation, Social, Education, Students

\section{Introduction}

The significance of the problem is related to the painful for society issue of the time for which the educational cases are being formed and realized, as well as their legal impact on the behavior of child offenders. Whether and how far it results, how does it influence their future development, what forms and governmental provisions the legislative framework has, and what is the effect of their implementation? Whether or not, by imposing educational measures, does the national legislative framework safeguard the rights of juvenile offenders? Is our current national legislation on child offenders unified with international and Community law in this regard?

The organization and realization of educational cases is a configuration of multi-faceted relationships. Its focus is on the effectiveness of the interaction between child offenders on the one hand, the institutions (municipalities, children's pedagogical rooms, child protection departments, schools, social institutions) involved in the realization of the educators' cases and the protection of the rights of the children and the parents or the authorized replacing them.

In this article, the authors draws attention to the timely formation and realization of educational cases and tries to examine them from the point of view of the existing national legislation, such as the Law on combating the antisocial behavior of juvenile offenders in the context of international and community law. The ultimate solution, the product of peer review, is the punitive measures that should be the result of timely intervention and well-functioning interinstitutional working coordination. These circumstances are important because remedial measures are seen as

\footnotetext{
${ }^{1}$ Lawyer, Associate Professor, PhD at the Department of Social sciences, Faculty of Medicine, Trakia University Stara Zagora, Rumvas2003@yahoo.com

${ }^{2} \mathrm{PhD}$ student at the Department of Social sciences, Faculty of Medicine, Trakia University - Stara Zagora, Vesela.mareva@gmail.com
} 
Vassliev, R. Mareva, V. (2018). The movement of proceedings in accordance with the actual national legisla-

tion in Bulgaria. International Journal of Social Sciences and Education Research, 4(1), 24-31.

preventive models which, if implemented in time and completeness, will achieve positive results in terms of future behavior of child offenders.

In the course of the petitions, we must understand the timely formation, scheduling and examination of the cases, their open and transparent conduct in compliance with the legal norms, the preparation of reasoned decisions provided at the meetings of the juvenile or juvenile offenders (respectively those representing them); The making of reasoned and reasoned proposals to the respective court, when the composition has ordered the imposition of measures within the meaning of Art. 13, para 1, item 11 and item 13 of the national law.

\section{Literature overview}

The contemporary legal doctrine of our country regarding the offenses committed by minors and minors corresponds in close proximity and up-to-date legal relation with the European legislation, prioritizing the processes of upbringing of juvenile and juvenile offenders. The etymology and philosophy of the legal figure of a culprit suggests that this type of cases is seen as elements of the process of upbringing juvenile offenders while at the same time realizing the possibilities of not violating their rights. The author considers the educational measures to support the educational process of child offenders as models that enrich their educational and cultural level alongside the learning process. The measures imposed are not accidentally called remedial, because everything related to the growth of children should be part of the process of their upbringing.

In the aspect of the analysis of educational measures as an educational element, a significant legal contribution is the application in our national legislation of the norms of many legal acts that regulate the process of child protection, among which are: The Council Decisions of the Council of Ministers of 19.07.2002 On Combating Trafficking in Human Beings (2002/629 / JHA) of 22.12.2003 on combating the sexual exploitation of children and child pornography (2004/68 / JHA) of 15.03.2001 on the protection of victims in criminal matters Cases / 2001/220 / JHA /; Resolution of the Council of Ministers of 20 December 1996 on drug trafficking (97 / C 10/02), Decision of the Council of Ministers of 28.05.2001 establishing a European crime prevention network / 2001/427 / JHA And the 2005 Council of Europe Convention on Action against Trafficking in Human Beings

According to Art. 11, para. 1 of the Law on combating the delinquency of juvenile offenders "Competent authority to consider educational cases for juvenile delinquency and crimes committed by minors exempt from criminal liability under Art. 61 of the Criminal Code is the local commission at their current address ". The structure, functions and limits of these committees are stipulated in Art. 6 of the national law. Their main functional feature is to work to divert offenders from criminal proceedings.

The local committees under this law may consider educational cases and impose educational measures, fulfilling the meaning of Art. 10, para. 1, b. "B" thereof, as well as to make proposals to the respective court for imposing the educational measures within the meaning of Art. 13 para. 1 , item 11 and item 13, ie when the measures are related to the placement of the juvenile offenders at the Social-Pedagogic Boarding Schools and in the Higher Education Boarding Schools. Essential function of the composition under Art. 11, para. 1 of the national law is to consider the educational measures even when the juveniles are perpetrators of antisocial acts but are exempted from criminal liability in the meaning of Art. 61 of the Penal Code. In considering such cases, it should be clarified that the full prescriptive condition of the Beijing Rules is that the case files of 
Vassliev, R. Mareva, V. (2018). The movement of proceedings in accordance with the actual national legislation in Bulgaria. International Journal of Social Sciences and Education Research, 4(1), 24-31.

the perpetrators of anti-social acts are redirected from the penal system and from the judiciary bodies to extrajudicial bodies, Ie they should be resolved by alternative structures outside the judiciary, such as local commissions. This condition confirms the fact that the national legislation unified under international law has subordinated its legal philosophy to the deviation from criminal justice of child offenders.

Thus, the legislation in force in Bulgaria implements the legal framework of criteria and requirements related to the protection of children offenders and the possibility that the process of their education and training should not be interrupted, even after the imposed sanction. By raising priority and protection of children's rights, the national law provides in Art. 19, para. 1 in the conduct of the meetings of the Chamber examining the educational cases the mandatory "... presence of his / her parent or of the person who substitutes him / her", and the following in para. 2 text obliges the representatives of the Child Protection Departments, who, along with the other specialists, members of the Commission, work on the cases under consideration.

The imperative of international and community law is the openness and transparency of justice processes when they are related to child justice. In this sense, advocating support for the universal human rights values of children, the legislator provided the opportunity before and during the examination of the educational cases that juvenile and juvenile offenders could benefit from the text of Art. 19, para. 3, which allows for representation by: "... a trusted representative or a lawyer".

As a permissible influence of international and Community law within the meaning of Art. 5, para. Article 4 of the Constitution of the Republic of Bulgaria - "International treaties ratified by constitutional order promulgated and entered into force for the Republic of Bulgaria are part of the domestic law of the country and take precedence over those norms of internal legislation that contradict them" is the impact of the European Convention on Human Rights and Fundamental Freedoms, the Charter of Fundamental Rights of the European Union and the Treaty of Lisbon amending the Treaty on European Union on the national law on the protection of the rights of minors Raids and deviations from criminal justice, as well as the possibility of bringing legal action against all imposed remedial measures. The norm of Art. 13 of the Convention is reiterated in the provision of Art. 47, para. 1 of the Charter of Fundamental Rights of the European Union, inasmuch as the Treaty of Lisbon has acceded to the Convention by the European Union.

The text of Art. 47, para. Article 1 of the Charter of Fundamental Rights of the European Union contained in Chapter VI of Justice provides that everyone whose rights and freedoms guaranteed by EU law have been violated is entitled to effective remedies, - the possibility of appealing to a court. At the same time, the text of Art. Article 13 of the Convention states that it concerns effective legal remedies for the protection of violated rights and freedoms. The provisions of Art. 47, para. 1 of the Charter of Fundamental Rights of the European Union, of Art. 6 and of Art. 13 of the European Convention for the Protection of Human Rights and Fundamental Freedoms, oblige the national legislature to provide in all cases the possibility for those whose rights and freedoms are violated to have effective legal remedies before a court.

The movement of educational cases, the imposition of educational measures and the progress of the legal process in the framework of the activity of the Ministry of Culture correspond to Chapter VI "Special rules for minors" by the National Assembly of the Republic of Bulgaria, which are in conformity with the texts of Art. 40 of the UN Convention on the Rights of the Child 
Vassliev, R. Mareva, V. (2018). The movement of proceedings in accordance with the actual national legisla-

tion in Bulgaria. International Journal of Social Sciences and Education Research, 4(1), 24-31.

and Rule 11 "Deviation from Criminal Justice" of the Beijing Rules, which refer cases of minors to the provisions of the Law on Combating Juvenile Delinquency of Juvenile Offenders as an Alternative Legal Opportunity To impose a sanction.

\section{Analysis}

The origin and the movement of educational cases is the possibility to look at the signals from children's pedagogical rooms, officials, parents, citizens and prosecutors. Several legal prerequisites are necessary for the initiation and movement of cases before the opinion of the Prosecutor's Office that the entire file of the pre-trial proceedings is transferred to the local commissions is to be undisputed.

The first precondition is that the act "does not pose a great social danger", and such an assessment is made according to the specific gravity of the act itself, the consequences of it on the perpetrator, on the others, on the victims, as well as on society.

The second prerequisite for the release of the juvenile from criminal liability under Art. 61, para. 1 of the Criminal Code, consists in the requirement that the act be committed "... because of enthusiasm or frivolity ...", which as its characteristic brings a marked taste of the psychological and mental characteristics relevant to the stage of minors that have stimulated the performance of the act.

The third prerequisite for the release of the juvenile from criminal responsibility has the effect and importance of having the first two. In practice, the realization of this premise by the decisionmaking body is its assessment of whether minors can successfully implement the educational measures under the Law on Combating Juvenile Delinquency and Non-Harmonious Offenders.

The complexity of formulating the assessment is entirely within the prerogatives of the competent decision-maker after a full analysis of all the characteristics of the perpetrator, after an analysis of his psychological profile, health status, family and living conditions in which he lives and develops, as well as his personal Qualities. The exemption from criminal liability within the meaning of Art. 61 of the Criminal Code can be implemented in all phases and stages of the process:

- the prosecutor before and during pre-trial proceedings;

-the court in the trial phase.

And in this sense, the legislator's will to seek alternative means of imposing a legal sanction for juvenile and juvenile delinquent acts is by no means a whim or a solution brought about by the modern times of today. From a legal and historical point of view, we can note that in Art. 5 of the Law on Courts of Minority (State Gazette No. 39 of 20 February 1943), the legislator has drawn up the legal possibility of alternative application of the criminal sanction by creating the following text: "The court may not impose the penalty Of the crime committed if it finds the corrective measure sufficient. " Even then, the legislator attempted and searched for various law enforcement options against deviant acts of minors.

With the actions implemented in the direction of the alternative of the penal sanction, in practice the national legislation also implements the implementation of the text under Art. 18. 1. of the Beijing Rules, according to which: "The competent authority must have a wide variety of measures that allow flexibility to maximize avoidance of placement in a public institution." One 
Vassliev, R. Mareva, V. (2018). The movement of proceedings in accordance with the actual national legislation in Bulgaria. International Journal of Social Sciences and Education Research, 4(1), 24-31.

of these measures, namely the possibility of implementing an alternative institutional consideration of the offenses of child offenders, is the examination of the file and the possible imposition of remedial measures by the composition of the local commission charged with this function under the national law.

The existence of the Institute for replacement of the punishments provided for in the Criminal Code under Art. 55, para. 1, item 2, b. "B" - where no lower limit of imprisonment is provided, it is replaced by probation or public reprimand, it should also be considered as an alternative measure to the juvenile delinquency.

The origin, as well as the possibilities for the formation of the educational cases are very diverse, but when they decide to impose remedial measures. In the analysis of the traffic according to the current national legislation, the following options are considered for the initiation and examination of educational cases by the local commissions:

- then received petitions for petitions;

- educational cases are being initiated at the suggestion of the police authorities;

- educational cases are initiated on a proposal of the prosecutor's office;

- educational cases are initiated on a proposal of the Prosecutor's Office, ie suspended by the District Prosecutor's Office under Art. 61 of the Criminal Code;

- educational cases are instituted on a court proposal;

- educational cases are initiated on a proposal of officials and citizens;

- Educational cases are initiated at the suggestion of other persons and organizations;

-the local commissions analyze the educational cases in general;

-the analyzed educational cases total, incl. Up to one month;

-the local commissions are informed of the terminated educational cases in total;

-the local commissions are informed of the terminated educational cases in total, sent by the Regional Prosecutor's Office;

-the local commissions are unqualified at the beginning of the reporting period;

-the local committees are analyzing the total number of educational cases initiated;

-the remaining unfinished cases are analyzed at the end of the reporting period, ie when the calendar year is overdue.

The presented broad-spectrum realities cover almost all the possibilities of the social and legal space that imply the formation and examination or non-formation and non-consideration of a criminal case. Social and life realities underline the public importance of the problem of the deviant behavior of juvenile and juvenile offenders. They are a reflection of concern and legal control of society on the behavior of this category of children on the other.

The focus of the legislator as an attempt to have a positive impact on this specific category of children is focused on the genesis of the conditions and problems that generate such behavior that are generated by family disharmony and are further developed in a negative way in the school 
Vassliev, R. Mareva, V. (2018). The movement of proceedings in accordance with the actual national legisla-

tion in Bulgaria. International Journal of Social Sciences and Education Research, 4(1), 24-31.

and street environment. Family education is directly related to socialization, and gaps in this period as an impact on children are seen as one of the main reasons for their deviant behavior and subsequent offenses committed by them.

In this sense, the family-child relationship is meaningful and multi-faceted, and its tearing is fatal to each other and ultimately reflects on society. It is no coincidence that the legislation in the enforcement of educational measures by the composition of the educational case requires, within the meaning of Art. 19, para. 1 of the Act, when these cases are dealt with to ensure the mandatory presence of: ".... to his / her parent or to the person who substitutes him / her". The author views this circumstance as a fact highlighting the need for family engagement and positive parental influence and impact on the behavior of child offenders.

Because not criminal repression, but the alternative to punishment, implemented through measures of educational and social impact on the deviant behavior of minors, is more like a positive change in the behavior of child offenders. As an alternative search for pedagogical effect and preventive approaches towards children who are perpetrators of antisocial actions, the educational measure is laid in the foundations of the legal framework regulating this type of legislation. The educational measures mentioned by the legislator are accepted by the author as alternative models and corrective mechanisms in the process of education and education of children offenders.

The philosophy of the educational measures imposed within the meaning of Art. 13 para. 1 of the Act is to implement a sanctional alternative to the perpetrators of anti-social acts. In this sense, the alternative to the imposition of a criminal sanction is due to the imperative provision 18.2. of the UN Rules on Minimum Standards Concerning Juvenile Crime (ie Beijing Rules), according to which: "No person of a full age may be Be wholly or partially deprived of parental supervision, unless the circumstances surrounding his case so require. " In this sense, the Convention on the Rights of the Child in Art. 40 para. 4 states that: "Various measures such as care, guidance and observation, counselling, conditional sentencing, rearing, education programs and other alternatives to placement in specialized institutions are presented to ensure that children are treated in such a way that, Appropriate to their well-being and consistent with both the situation and the breach ". In view of this, the Beijing UN Rules on Minimum Standards Concerning Juvenile Crime offer specific varied measures as an alternative to the deprivation of liberty listed in Chapter 18 - "Different Criminal Measures", but according to Rule 18. 1. "The Competent Authority Must have a variety of measures that allow flexibility in order to maximally avoid placement in a public institution. "

These models, operating in the legal area of international and Community law, have an unconditional influence on national law.

The movement of educational cases and the imposition of corrective measures by the composition of local committees under the Law on combating the anti-social acts of juvenile offenders is an important indicator in terms of respecting the rights of minors, especially since these measures are different from the punishment Its essence. In practice, they pursue different objectives that can be addressed in at least two aspects:

The first aspect is woven from the formal point of view of law and contains several elements, such as: 
Vassliev, R. Mareva, V. (2018). The movement of proceedings in accordance with the actual national legislation in Bulgaria. International Journal of Social Sciences and Education Research, 4(1), 24-31.

- the correction and re-education of the perpetrators of anti-social acts, which according to Art. 1 of the national law is limited to: "... ensuring the normal development and education of the perpetrators" (of anti-social acts);

- unlike punishment, coercion is not always an element of the educational measure;

A particular peculiarity of the educational measures distinguishing them from the punishment lies in the difference of the institutions imposing them, which circumstance can be accepted as an element proving the alternative of the sanction, because the sanctioning body is neither a prosecution nor a court but a structure, Created by a special law and operating under different legal order.

The second aspect is of no less value and is limited to the possibility for the minors to impose the measures: "Accommodation in social-pedagogic boarding schools" and "Accommodation in a correctional boarding school".

In this respect, the legislator has deprived the legal committees of the law of imposing these remedial measures, as they are, in essence, insulating and in practice the most severe form of coercion over juvenile delinquents. From the point of view of the protection of their rights to the most serious injunction, only the relevant court, ie the court of law, which has the opportunity and the right to realize alternatives when applying a corrective measure instead of criminal, So as not to violate the process of educating offenders either in the educational or in the psycho-physical aspect.

Educational measures should not be seen as a form of state coercion because they are aimed at influencing educational, educational, non-compulsive, non-violent offenses against juvenile offenders.

In this sense, the movement of educational measures is an important indicator of the successful work of each local commission working under the law on combating the antisocial behavior of juvenile and juvenile offenders. The possibilities for formation and realization of educational cases, ie their movement, are multi-aspect and temporal as a reflection on the possibility of adequate and timely intervention towards the perpetrators of anti-social acts. The movement of educational cases is a typical legal sign of the proper work of each local commission, of its adequate and timely administrative and legal intervention.

The aim in the process of the movement of pecuniary deeds is:

- the prompt, lawful and adequate institutional intervention in time from the commission of the anti-social acts, the knowledge of them by the institutions, and the carrying out of the necessary operative-search events and interrogations;

Their resolutions on the part of the recourse party, which should seek and enforce the most equitable and lawful educational measures that are appropriate to the extent of their burden and public influence, as well as the age and personality characteristics of child offenders.

\section{Conclusion}

The movement of educational cases according to the national legislation in force of our country author accepts as an element of the process of legal and educational socialization of children offenders. Let us not forget that our democratic civil society is particularly sensitive on the issue of justice against child offenders, and in this sense, it would have a lasting and positive effect on 
Vassliev, R. Mareva, V. (2018). The movement of proceedings in accordance with the actual national legislation in Bulgaria. International Journal of Social Sciences and Education Research, 4(1), 24-31.

it if the basic legal principles stemming from national law are implemented in a timely and adequate manner or as they are the ancient saying: "Nothing guarantees the calm and consent of the citizens of a country better than the exact implementation of the laws."

The movement of educational cases has a particular impact on the condition, structure and trends of antisocial acts committed by child offenders, because it also influences the processes of resocialization of young people with problematic behavior. In this sense, the local commissions under the Act on the Anti-Juvenile Delinquency of Minor and Juvenile Offenders are responsible for the movement of educational cases, such as reflection of the committed anti-social acts and the timely imposition of remedial measures.

Through the movement of educational cases, as an essential part of the national legislation, its main goals and tasks are fulfilled, including the timely and detailed examination of the educational cases and the imposition of the appropriate corrective measures for the child offenders of antisocial acts, by prioritizing the models to work with them.

\section{References}

Constitution of the Republic of Bulgaria Prom., SG, no. 56 of 13. 07. 1991, in force from 13.07. 1991

Anlaw for combating the anti-social acts of juvenile offenders, dated 14 February 1958

UN Rules on Minimum Standards Concerning Juvenile Crime - "Beijing Rules", adopted on 29 November 1985 by United Nations General Assembly Resolution 40/33.

European Convention on Human Rights and Fundamental Freedoms - Rome, 04. 09. 1950

Charles of Fundamental Rights of the European Union 2012 / C 326/02

Treaty of Lisbon amending the Treaty on European Union, signed in Lisbon on 13.12.2007

United Nations Convention on the Rights of the Child, adopted by the United Nations General Assembly on 20.11.1989, ratified by a resolution of the Bulgarian National Defense Council of 11. 04. 1991, SG No. 32 of 23.04.1991 in force from 03.07.1991

Law on courts for minorities, prom. SG no. 39 of 20 February 1943 